\title{
Breeder Nutrition and Offspring Performance ${ }^{1}$
}

\section{author(s)}

Calini Fa*

Sirri $F^{b}$

a Consultant to the Feed \& Animal Industry.

b Department of Food Science, Alma Mater Studiorum - University of Bologna, Via S. Giacomo, 9, 40126 Bologna, Italy.

\section{Mail Address}

\section{FCalini}

Via F.lli Ferrucci, 40

48022 Lugo (RA), Italy

E-mail: tecnas@alinet.it

\section{Keywords}

Broiler breeder, progeny, nutrition.

1 Presented at the XII European Poultry Conference, Verona, Italy, 10-14, September 2006.

\section{ABSTRACT}

Vertical integration in poultry industry strongly emphasizes the importance of cost control at all levels. In the usual broiler production operations, the costs involved with the production of the hatching egg or the day old chick are negligible if seen in the perspective of the cost per $\mathrm{kg}$ of live bird.

From a research point of view, anyway, the greatest attention is usually given to the performance of broiler breeders, and most of the research in the field is focused on the improvement of their relative performance, mainly in terms of saleable chicks produced per hen, while less attention has been given to the quality of the chick and to the improvement of its growth performances, even if these last parameters have an effective impact on the overall economics of the poultry growing business. Most of the data available is quite dated, as can be seen from some recent reviews, and in general little attention is given to the impact of parental nutrition on the subsequent broiler performance. It is in fact more usual to find data about dam nutrition influence on egg fertility and hatchability than on subsequent progeny performance.

The objectives of this review were to assess, on the basis of published reports, the effects of selected nutrients and anti-nutrients normally prevailing in commercial broiler breeder feeds - vitamins, micro-minerals, mycotoxins, - trying to pinpoint which could be the positive and the negative effects of both on the subsequent broiler performance, with a particular attention to the impact on immune function and carcass yield.

\section{INTRODUCTION}

The nutrition of breeding hens has been subjected to a steady improvement in the years, and the more it came clear how to feed them in order to obtain the best production and fertility, the smaller became the field of possible improvement.

The possibility of improving broilers production parameter by means of manipulation of the parent stock diets has been the subject of research for many years, with the aim to find ways to influence the growth of their offspring in a most economical way.

This is due to the fact that the relative incidence of layer feed costs on the total feed cost of production of one live bird is very small, as it can be seen from the calculations shown in Table 1 and 2, and Equations $1,2,3,4$ and 5 . 


\section{Breeders}

\begin{tabular}{cccc}
\hline Table $\mathbf{1}$ - Basis of estimating breeders feed cost & & \\
$\mathbf{k g}$ of feed per & chicks per hen housed \\
from $\mathbf{2 4}$ to $\mathbf{6 3} \mathbf{~ w s}$ & $\mathbf{k g}$ of feed per hen \\
$\mathbf{1 0 0}$ chicks hatched & 145 & from $\mathbf{0}$ to $\mathbf{2 3} \mathbf{~ w s}$ & $\begin{array}{c}\text { kg of layer feed per } \\
\mathbf{1} \text { hatched chick }\end{array}$ \\
40.6 & & 13.9 & 0.31 \\
\hline
\end{tabular}

\section{Calculation of the amount of feed:} $\mathrm{kg}$ of feed per 145 chicks:

$40.6 \times 1.45=58.9$

Eq.1

$\mathrm{kg}$ of feed per hen housed from 24 to $63 \mathrm{wks}$ :

$58.9-13.9=45.0$

Eq.2

$\mathrm{kg}$ of feed per 1 chick hatched:

$45 / 145=0.31$

\section{Impact of maternal macronutrient, mineral and vitamin nutrition on progeny}

A recent paper (Kidd, 2003) gives an excellent review on the possibility to impact the offspring performance by means of manipulation of dam's

Eq.3 nutrition. We will try to update this option with the most recent findings.

\section{Broilers}

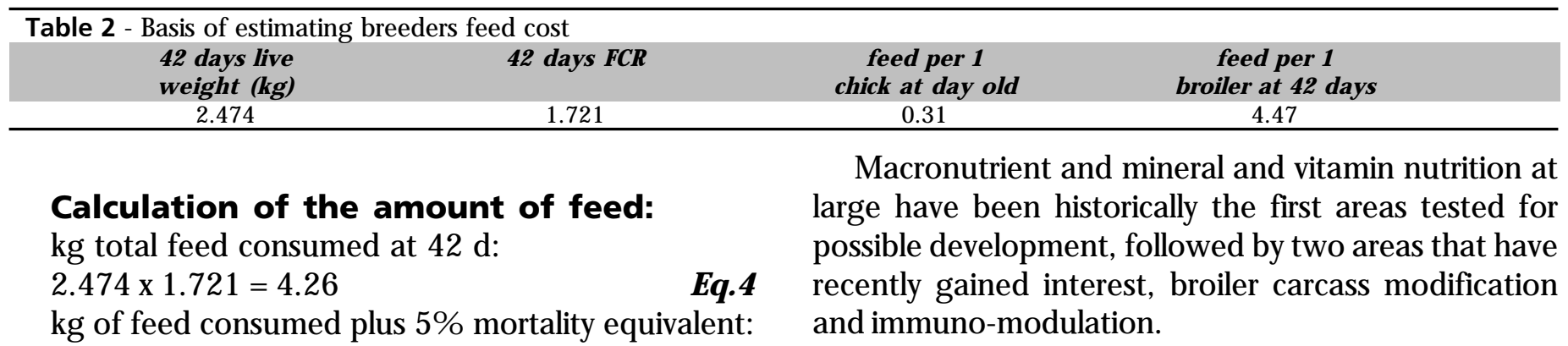

$4.26 \times 1.05=4.47$

Eq.5

Ratio $\left\{\frac{\text { Feed per } 1 \text { chick at day old }}{\text { Feed per } 1 \text { broiler at } 42 \text { days }}\right\} \times 100=-\left\{\frac{0.31}{4.47}\right\} \times 100=6.94 \% \quad$ Eq.6

Any nutrient manipulation of layer feed has then a minimal impact on the overall feed costs of broiler production since, as shown above, the maternal feed consumption for one hatched chick accounts for less than $7 \%$ of the total feed consumed by the chicken during growth. This explains why this research area is so interesting, considering how huge the return could be. A problem arising in this field has always been the need to distinguish between nutrient manipulations that gave their positive effect on broilers by means of a better - or more appropriate - nutrition of the dams, and real improvement of broiler performance through nutritional manipulation of their mother's diets, whose effects "jump" onto the offspring. The first ones are as interesting as the latter from an economical point of view, but much easier to verify and put into practice, as it has been done.
Let's take into consideration the macro-nutrient side of breeder nutrition (Table 3).

It can be easily seen that, as the available data on protein and energy is quite dated and spread on a large date interval, the evolution of the genetic background of the birds tested casts doubts on the relevance of the overall data for today's birds.

Some of the nutrient manipulations presented have been put to work in practical diets, like the reduced protein levels later in lay, as most of the positive ideas presented have either become integral part of the knowhow in poultry reproduction or abandoned because not feasible due to genetic or managerial problems.

M ineral nutrition trials (Table 4 ) show little improvement - one recent paper about organic manganese and zinc supplementation (Virden et al., 2003) - while most test are more relevant as deficiency assessment than as positive dietary manipulation. 


\begin{tabular}{|c|c|c|c|}
\hline $\begin{array}{l}\text { Nutrients modification } \\
\text { in breeder feed }\end{array}$ & on progeny & Parameter & Authors \\
\hline \multicolumn{4}{|l|}{ CP, TSAA, Lysine, Arginine, Tryptophane } \\
\hline 15 or $17 \%$ CP & Yes & FCR at $41 \mathrm{~d}$ (best with low CP) & Prrtoudfoot et al., 1985 \\
\hline $9,11,13,15 \%$ CP & Yes & $\begin{array}{l}\text { Body weight at hatch and at } 24 \mathrm{~h} \\
\text { only in female(higher with } 15 \% \mathrm{CP} \text { ) }\end{array}$ & Lopez \& Leeson, 1994 \\
\hline $9,11,13,15 \% \mathrm{CP}$ & No & $\begin{array}{l}\text { Productive performance and carcass } \\
\text { traits at } 49 \mathrm{~d}\end{array}$ & Lopez \& Leeson, 1994 \\
\hline $10,12,14,16 \% \mathrm{CP}$ & Yes & $\begin{array}{l}\text { Chick weight at hatch } \\
\text { (lower with } 10-12 \% \mathrm{CP} \text { ) }\end{array}$ & Lopez \& Leeson, 1995a \\
\hline $10,12,14,16 \% \mathrm{CP}$ & No & Body weight up to $48 \mathrm{~d}$ & Lopez \& Leeson, 1995b \\
\hline $\begin{array}{l}14.6 \% \mathrm{CP}, 2490 \mathrm{kcal} / \mathrm{kg} \mathrm{ME} \text { vs } 17.5 \% \mathrm{CP}, \\
2880 \mathrm{kcal} / \mathrm{kg} \mathrm{ME}\end{array}$ & Yes & $\begin{array}{l}\text { Growth rate at } 42 \text { and } 63 \mathrm{~d} \\
\text { (higher with high density diet) }\end{array}$ & Aitken et al., 1969 \\
\hline $1.88,1.73,1.52 \mathrm{MJ} \mathrm{MEa}$ and 19.4 or $27.2 \mathrm{~g} \mathrm{CP} / \mathrm{bird} / \mathrm{d}$ & No & Growth rate, FCR, mortality & Pearson \& Herron, 1981 \\
\hline $13.1 \% \mathrm{CP}+12.2 \mathrm{MJ} / \mathrm{kg}$ vs $16 \% \mathrm{CP}+11.3 \mathrm{MJ} / \mathrm{kg}$ & No & Productive performance & Proudfoot \& Hulan, 1986 \\
\hline $19,25 \mathrm{~g} \mathrm{CP}$ and $325,385,450 \mathrm{kcal} / \mathrm{kg} \mathrm{ME}$ & Yes & $\begin{array}{l}\text { Body weight in male chicks at } 1 \text { and } \\
20 \mathrm{~d} \text { (higher with } 450 \mathrm{kcal} / \mathrm{kg} \mathrm{ME} \text { ) }\end{array}$ & Spratt \& Leeson (1987a) \\
\hline $19,25 \mathrm{~g} \mathrm{CP}$ and $325,385,450 \mathrm{kcal} / \mathrm{kg} \mathrm{ME}$ & Yes & $\begin{array}{l}\text { Increased carcass protein and } \\
\text { decreased carcass fat at } 41 \mathrm{~d} \\
\text { (with } 450 \mathrm{kcal} / \mathrm{kg} \mathrm{ME} \text { ) }\end{array}$ & Spratt \& Leeson (1987a) \\
\hline Increasing $\mathrm{CP}$ and energy & Yes & Body weight, particularly of male & Brake et al. (2003) \\
\hline High energy in male breeder & Yes & Body weight at $42 \mathrm{~d}$ & Attia et al., (1993, 1995a) \\
\hline Oleic, linoleic and linolenic & Yes & Fatty acid composition of embryos & Cherian \& Sim, 1993 \\
\hline Palm butter, safflower oil & No & Body weight at $35 \mathrm{~d}$ & Halle, 1999 \\
\hline No added fat, corn oil, poultry oil, lard & No & $\begin{array}{l}\text { Body weight, FCR, feed intake, } \\
\text { liver weight from day } 1 \text { to } 22\end{array}$ & Peebles et al., 1998 \\
\hline 1,5 or $3 \%$ corn, poultry or coconut oil & Yes & $\begin{array}{l}\text { Body weight, front half carcass yield } \\
\text { at } 43 \text { days }\end{array}$ & Peebles at al., 1999b \\
\hline Less saturated fat & Yes & Live performance and carcass yield & Peebles et al., 2002b \\
\hline Nutrients modification in breeder feed & on progeny & Parameter & Authors \\
\hline Restricted calcium levels & Yes & Chick body weight at hatch & Buckner et al., (1925) \\
\hline 2,6 , and $10 \mathrm{~g} / \mathrm{kg}$ of avail. $\mathrm{P}$ & No & Body weight at hatch & Triyuwanta et al., (1992) \\
\hline 2,6 , and $10 \mathrm{~g} / \mathrm{kg}$ of avail. $\mathrm{P}$ & Yes & Progeny ossification at hatch & Triyuwanta et al., (1992) \\
\hline $\begin{array}{l}\text { Addition of } 3,5 \mathrm{~g} / \mathrm{kg} \text { defluorinated } \mathrm{P} \\
\text { to } 3,4 \text { and } 3,9 \mathrm{~g} / \mathrm{kg} \text { diets }\end{array}$ & No & $\begin{array}{l}\text { Ash, calcium and phosphorus levels of } \\
\text { chick tibia at hatch and } 2 \text { wks post hatch }\end{array}$ & Harms et al., (1964) \\
\hline $15 \mathrm{mg} \mathrm{zinc} / \mathrm{kg}$ & Yes & No zinc deficient symptoms & Turk et al., (1959) \\
\hline 28,34 or $40 \mathrm{mg}$ zinc $/ \mathrm{kg}$ & Yes & $\begin{array}{l}\text { Feather fraying with unsupplemented } \\
\text { diets }(28-34 \mathrm{mg} / \mathrm{kg})\end{array}$ & Stahl et al., (1986) \\
\hline 28,34 or $40 \mathrm{mg}$ zinc $/ \mathrm{kg}$ & No & Growth from hatch to 21 days & Stahl et al., (1986) \\
\hline $0,20,200$ and $2000 \mathrm{mg}$ zinc $/ \mathrm{kg}$ & No & $\begin{array}{l}\text { Body weight or zinc, copper and iron } \\
\text { metabolism at } 21 \text { days }\end{array}$ & Stahl et al., (1990) \\
\hline $\mathrm{BD}(100 \mathrm{mg}$ zinc $/ \mathrm{kg})+80 \mathrm{mg} / \mathrm{kg}$ zinc methionine & Yes & $\begin{array}{l}\text { Improved survival to an Escherichia coli } \\
\text { challenge }\end{array}$ & Flinchun et al., (1989) \\
\hline $\begin{array}{l}\mathrm{BD}(100 \mathrm{mg} \text { zinc } / \mathrm{kg})+40 \mathrm{mg} / \mathrm{kg} \text { zinc oxide } \\
\text { or zinc methionine }\end{array}$ & Yes & $\begin{array}{l}\text { Improved cellular immunity } \\
\text { (only with zinc methionine) }\end{array}$ & Kidd et al., (1992) \\
\hline $\begin{array}{l}\mathrm{BD}(72 \text { or } 82 \mathrm{mg} / \mathrm{kg})+40 \mathrm{mg} / \mathrm{kg} \text { of zinc oxide } \\
\text { or zinc methionine }\end{array}$ & Yes & $\begin{array}{l}\text { Improved humoral immunity (only with } \\
\text { zinc oxide), improved cellular immunity } \\
\text { (only with zinc methionine) }\end{array}$ & Kidd et al., (1993) \\
\hline Manganese deficiency & Yes & $\begin{array}{l}\text { Abnormal shortening of the bones in } \\
\text { embryo and progeny }\end{array}$ & Caskey \& Norris, (1940) \\
\hline $\begin{array}{l}\text { BD }(75 \mathrm{mg} / \mathrm{kg} \text { zinc and } 83 \mathrm{mg} / \mathrm{kg} \text { manganese })+ \\
75 \mathrm{mg} / \mathrm{kg} \text { zinc }+80 \mathrm{mg} / \mathrm{kg} \text { manganese }\end{array}$ & Yes & $\begin{array}{l}\text { Improved liveability from } 1 \text { to } 18 \mathrm{~d} \text { and } \\
\text { from } 1 \text { to } 34 \mathrm{~d} \text { with organic forms of } \mathrm{Zn} \\
\text { and } M \mathrm{n} \text { vs inorgarnic form }\end{array}$ & Virden et al., (2003) \\
\hline 0 or $0.03 \mathrm{mg} \mathrm{Se} / \mathrm{kg}$ & Yes & Poor growth in deficient diet & Cantor \& Scott, (1974) \\
\hline 0.05 or $0.1 \mathrm{mg} \mathrm{Se} / \mathrm{kg}$ & Yes & $\begin{array}{l}\text { Bilateral paralysis and skeletal and } \\
\text { muscular degeneration with deficient die }\end{array}$ & Bains et al., (1975) \\
\hline $100 \mathrm{mg} / \mathrm{kg}$ of sodium fluoride in drinking water & No & Growth in progeny until 28 days & Merkley \& Sexton, (1982) \\
\hline $0,300,600,900$ and $1200 \mathrm{mg}$ fluoride/kg & No & $\begin{array}{l}\text { Growth rate and FCR from hatch } \\
\text { to } 14 \text { days }\end{array}$ & Van Toledo \& Combs, (1984) \\
\hline Mg deficient diets & Yes & $\begin{array}{l}\text { Chicks with convulsions and comas } \\
\text { that died within } 2 \text { days }\end{array}$ & Sell et al., (1967) \\
\hline
\end{tabular}


Most of the vitamin trials reported (Table 5) show the importance of an adequate vitamin supply to the dams in order to avoid deficiency problems in the chicks, but cannot demonstrate the benefits of increasing the levels above recommended - with some notable exceptions like vitamin $D_{3}$ (Ameenuddin et al., 1986) and its derivatives (Atencio et al., 2005b, c) and vitamin $\mathrm{E}$ (Haq et al., 1996; Hossain et al., 1998) - and often show problems of toxicity or are too old to be fully relevant.

An interesting report (Hossain et al., 1998) indicates that high concentrations of vitamin $E$ in hen feeding support not only better progeny performance but also their ability to increase the immune response; how ever the in ovo administration of vitamin was more effective in increasing the antibody response.

Rebel et al. (2004), investigating the effect of high dietary supplementation of vitamin and trace element premix in broiler breeder, confirmed the importance of some micronutrients in modulating the immune response in birds. The Authors observed a fast recovery in the state of the intestine of broilers hatched from breeders fed the high supplemented premix after $M$ alabsorption Syndrome (M AS) inoculation associated to a higher level of lymphocytes in day old chicks.

It is well documented that in general nutrition might greatly affect immuno-competence in birds, with particular regard to vitamins and minerals (Latshaw,

\begin{tabular}{|c|c|c|c|}
\hline Nutrients modification in breeder feed Effects & on progeny & Parameter & Authors \\
\hline 363, 544, 2,268 IU Vit. A /kg diet & Yes & Accelerated growth with $2,268 \mathrm{IU}$ vit $\mathrm{A}$ & Hill et al., (1961) \\
\hline $\begin{array}{l}\beta \text {-carotene, cantaxhanthin, lutein } \\
\text { and vitamin } \mathrm{E}\end{array}$ & Yes & $\begin{array}{l}\text { Bursal and splenic lymphocyte proliferation } \\
\text { (vit. } E \text { and } \beta \text {-carotene), humoral immunity } \\
\text { (increased by vit.E and reduced by } \beta \text {-carotene) }\end{array}$ & Haq et al., (1996) \\
\hline Vit. E and Se deficient diet & Yes & $\begin{array}{l}\text { Reduced growth and plasma tocopherols and } \\
\text { increased exudative diathesis }\end{array}$ & Combs, (1976) \\
\hline 0 to $120 \mu \mathrm{g} / \mathrm{g}$ of retinol equivalents & Yes & High liver lipid peroxidation with excess of vit. A & Surai et al., (1998) \\
\hline 0 or $150 \mathrm{mg} / \mathrm{kg}$ vit. $\mathrm{E}$ & Yes & $\begin{array}{l}\text { Higher agglutination titers at } 2 \text { and } 7 \text { days } \\
\text { (150 mg/kg vit E) }\end{array}$ & Jackson et al., (1978) \\
\hline $\begin{array}{l}5,000 \mu \mathrm{g} / \mathrm{kg} \text { cholecalciferol } \\
0,1,10 \mathrm{mg} \text { vitamin } \mathrm{K}_{1} / \mathrm{kg} \text { or } 1,10 \mathrm{mg} / \mathrm{kg}\end{array}$ & Yes & Higher tibia ash & Ameenuddin et al., (1986) \\
\hline menadione sodium bisulfite & Yes & $\begin{array}{l}\text { Prothrombin levels were higher in chicks } \\
\text { fed vit. } K_{1}\end{array}$ & Griminger (1964) \\
\hline Vit. $\mathrm{K}$ deficient or adequate diets & Yes & $\begin{array}{l}\text { Blood clotting time increased with deficient } \\
\text { diets }\end{array}$ & Lavelle et al., (1994) \\
\hline Biotin deficient diet & Yes & Leg abnormalities & Cravens et al., (1944) \\
\hline $0,20,40,60,100,180,340 \mu \mathrm{g}$ biotin $/ \mathrm{kg}$ & Yes & $\begin{array}{l}\text { Higher body weight at } 14 \text { days with biotin } \\
\text { supplementation }\end{array}$ & Brewer \& Edwards (1972) \\
\hline Deficient biotin diets & Yes & $\begin{array}{l}\text { Reduced plasma biotin at hatch, reduced } \\
\text { viability and growth }\end{array}$ & Whitehead et al., (1985) \\
\hline Deficient biotin diet & No & $\begin{array}{l}\text { Male and female progeny body weight } \\
\text { at } 0 \text { and } 21 \text { days }\end{array}$ & Leeson et al., (1979 a) \\
\hline $200 \mathrm{mg}$ biotin/kg & Yes & $\begin{array}{l}\text { Reduced foot pad dermatitis and incidence } \\
\text { of breast blisters in progeny }\end{array}$ & Harms et al., (1979) \\
\hline Riboflavin deficient diet & Yes & Curled toe paralysis & Whitehead et al., (1993) \\
\hline Riboflavin deficient diet & No & Growth rate & Leeson et al., (1979a) \\
\hline Vit. $B_{12}$ deficient diet & No & Growth rate & Leeson et al., (1979b) \\
\hline 0 or $10 \mu \mathrm{g}$ vit. $B_{12} / \mathrm{kg}$ diet & Yes & $\begin{array}{l}\text { Enhanced body weight gain at } 21 \text { days } \\
\text { (with } 10 \mu \mathrm{g} \text { vit. } \mathrm{B}_{12} / \mathrm{kg} \text { diet) }\end{array}$ & Patel \& McGinnis, (1977) \\
\hline 6-8 mg pantothenic/kg diet & Yes & Better viability and growth rate & Beer et al., (1963) \\
\hline 6.6 and $9.9 \mathrm{mg}$ pantothenic/kg diet & Yes & Improved body weight gain at 10 days & Balloun and Phillips, (1957) \\
\hline Pantothenate deficient diet & No & Growth rate & Leeson et al., (1979a) \\
\hline $25,50,75,100$ ppm vit. $E$ & Yes & $\begin{array}{l}\text { Higher body weight, better FCR, lower mortality, } \\
\text { higher immune response to ND vaccine with high } \\
\text { level of vit. E }\end{array}$ & Hossain et al., (1998) \\
\hline $0,2.5,5 \mathrm{mg} / \mathrm{egg}$ vit. $\mathrm{E}$ in ovo injection & Yes & $\begin{array}{l}\text { Higher body weight, better FCR, lower mortality, } \\
\text { higher immune response to ND vaccine }\end{array}$ & Hossain et al., (1998) \\
\hline High or low vitamin and trace mineral premixes & Yes & Higher blood cell and specific antibody reaction & Rebel et al., (2004) \\
\hline $0,125,250,500,1,000,2,000,4,000 \mathrm{lU} / \mathrm{kg}$ vit. $\mathrm{D}_{3}$ & Yes & $\begin{array}{l}\text { Body weight gain and lower Ca rickets incidence } \\
(2,000 \text { or } 4,000 \mathrm{IU})\end{array}$ & Atencio et al. (2005a) \\
\hline $\begin{array}{l}0,3,125,12,500,50,000 \mathrm{ng} / \mathrm{kg} \text { vit. } \mathrm{D}_{3} \text { or } \\
3,125 \text { and } 12,500 \mathrm{ng} / \mathrm{kg} 25-\mathrm{OHD}_{3}\end{array}$ & Yes & $\begin{array}{l}\text { High body weight, } \mathrm{FCR} \text {, bone ash, low mortality } \\
\text { (with high level of vit. } \mathrm{D}_{3} \text { or } 25-\mathrm{ODH}_{3} \text { ) }\end{array}$ & Atencio et al. (2005b) \\
\hline $\begin{array}{l}0,125,250,500,1,000,2,000,4,000 \mathrm{lU} / \mathrm{kg} \text { vit. } \mathrm{D}_{3} \\
\text { or } 3,125 \text { and } 12,500 \mathrm{ng} / \mathrm{kg} 25-\mathrm{OHD}_{3}\end{array}$ & Yes & $\begin{array}{l}\text { High body weight gain, tibia ash and low leg and } \\
\text { bone disorders (with high level of vit. } \mathrm{D}_{3} \text { or } 25-\mathrm{ODH}_{3}\end{array}$ & Atencio et al. (2005c) \\
\hline 0, $25 \mathrm{mg} \mathrm{L-carnitine/kg}$ & Yes & $\begin{array}{l}\text { Low carcass fat and high breast meat } \\
\text { (in progeny fed high density diet) }\end{array}$ & Kidd et al., (2005) \\
\hline
\end{tabular}


1991). The effect of nutrients has been more largely explored in broiler chicken nutrition rather than in broiler breeder and their progeny, so further researches are needed for better elucidate the immunomodulatory nutrient requirement that will positively impact the overall health of chickens and, consequently, profitability in poultry industry.

\section{Effects of nutrients manipulation in broiler breeder feeding on progeny carcass traits}

This section addresses to the latest published reports that have not been dealt in the previous review (Kidd, 2003).

It is worldwide recognized that in broiler breeder formulation several parameters have to be taken into account: in particular requirements for maintenance, growth and reproduction need to be carefully considered for maximizing the reproductive and productive performances of parents. Thus, the nutrient profile commercially adopted to obtain the best performance from breeders has been selected to obtain the highest economically productive performance, represented by the number of saleable chicks produced per hen. However, good breeder hen performances and also hatchability do not necessary positively correlate with high percentage chicks of good quality with high liveability and growth potential (Decuypere $\&$ M ichels, 1992). Therefore a gap among the goals of breeding, hatchery and farming exists since very little attention has been paid, from the top of the chain, to the quality of day-old chicks for the reason that is not yet fully perceived as high performance potential chicks.

Starting from these considerations, a "new concept" has been developed based on the possibility of positively influencing the offspring performance with particular regard to their carcass composition, through adequate supplementation and balance of nutrients in dam nutrition.

The effect of nutrient manipulation in broiler breeder feeding on progeny carcass composition was firstly explored and documented by Spratt \& Leeson (1987). The Authors observed that protein and energy in dam nutrition can alter the carcass fat and protein deposition of offspring at slaughtering and processing. In particular, providing $150 \mathrm{~g}$ of feed per days with 19 or $25 \mathrm{~g}$ of crude protein and 325,385 or $450 \mathrm{kcal} / \mathrm{kg} \mathrm{ME}$ from 19 weeks onwards, the progeny performances of chicks hatched at weeks 29, 32, 36 and 40 were monitored. Beside a better growth rate of male progeny chicks from hens receiving the highest energy diet (450 $\mathrm{kcal} / \mathrm{kg} \mathrm{ME}$ ) an increased protein retention with a reduced fat deposition at 41 days of age was observed in comparison with chicks of hens receiving the low est energy diet $(325 \mathrm{kcal} / \mathrm{kg})$.

Some other experiments aiming at understanding the role of the type of fat included in the maternal diet on the offspring body composition at slaughter were carried out by Peebles et al., (1999; 2002). Different fat sources such as corn oil, poultry fat and lard and two levels of inclusion, 1.5 and 3\%, were tested in broiler breeder hens and their effects were monitored on progeny hatched at 35, 51 and 63 weeks. Corn oil had a positive effect on progeny at days 43 by enhancing the proportion of carcass yield (breast, wings and back) compared with the animal origin fat. These findings demonstrate that a reduction of the unsaturated-saturated ratio in hen feeding positively impacts on progeny carcass yield at processing.

Furthermore, the effect of L-carnitine supplementation $(25 \mathrm{mg} / \mathrm{kg})$ in breeder hen diet on progeny performance and carcass traits was recently investigated by Kidd et al. (2005). The Authors demonstrated that the hen dietary manipulation affects carcass fat and breast meat differently in male and female progeny. Indeed, offspring from hens receiving no supplemented diet produced male with lower relative fat than female and this effect decreases in progeny from hens with supplemented diets. Moreover the L-carnitine supplementation was able to reduce the difference of relative breast meat yield between male and female where it is commonly higher in the latter. The Authors postulated that L-carnitine inclusion in hen diets modified the energy metabolism in progeny making fatty acids and energy more available and consequently allowed males for higher tissue accretion because of their rapid growth rate. However these results were observed only with hens fed high, but not low, density diets. This nutritional approach represents a successful and cheap strategy to improve the efficiency of the poultry food chain and, in general, this opportunity should be further investigated with the aim of better understand the breeder hen nutrient requirements in relation to the maximization of the offspring overall performance.

As already mentioned, great attention has been focused on the possibilities to stimulate the early growth of the chicks, starting from the embryonic stage, by providing the egg with higher concentrations of micronutrients with particular regard to vitamins. It is 
well known that the egg vitamin profile it is easily modifiable through the hen nutrition and this possibility might represent an important tool also in breeder nutrition to deliver essential nutrients in proper amount in the yolk sac with the aim of positively modifying some metabolic processes occurring during the embryonic life and early growth phase of chicks.

A clear effect of the influence of the maternal dietary regimen on the progeny performance and particularly on bone characteristic was highlighted by a series of recent works (Atencio et al., 2005 a, b, c). These studies explored the possibilities to improve the bone formation efficiency to reduce the incidence of leg abnormalities and metabolic calcium related imbalances through the dietary maternal supplementation of increasing levels of vitamin $D_{3}$ or $25-\mathrm{OHD}_{3}$. Interestingly, the progeny hatched from hens supplemented with high doses of vitamin $D_{3}$, showed better performance (higher body w eight gain), tibia ash content and low er leg abnormalities when fed different calcium levels. How ever, the supplementation of 25$\mathrm{OHD}_{3}$ a vitamin D metabolites, in the offspring's diet reduced the effects of the inclusion of high levels of vitamin $D_{3}$ in the maternal diet. M oreover, also the dam supplementation of $25-\mathrm{OHD}_{3}$, as described for vitamin $D_{3}$ improves the same progeny performance. The authors concluded that, when comparing vitamin D sources in the feeding of breeder hens and on their progeny, $25-\mathrm{OHD}_{3}$ has greater potency than $\mathrm{D}_{3}$ only at very low levels of supplementation. In general, from these works clearly emerge that the breeder hen requirements for vitamin $D_{3}$ and its derivatives to produce effects on progeny performance and health is considerably higher than the NRC (1994) recommendations and to the levels allowed by the current EU regulation.

\section{Effects of toxic compounds in broiler breeder feeding on progeny}

The deleterious effects of some compounds that accidentally may contaminate breeder hen feed such as fungal metabolites or toxic products and their repercussions on progeny health status and performance have not received from a scientific point of view as much attention as the dietary nutrients. As reviewed by Kidd (2003), researches on this topic are sparse (Table 6 ). The effects of mycotoxins contamination of breeder feed has been mainly focused on Aflatoxins and Zearalenone and the biggest concern and threat related to their transfer to from dam to egg is represented by the impact they exerts on progeny immune function (Qhreshi et al., 1998). Further investigations should be addressed in this field to verify the impact of other classes of mycotoxins normally occurring in feedstuffs for poultry with particular regard to the effects exerted on immune response. Indeed, nowadays due to the negative effect of intensive genetic selective processes and to the ban of most growth promoter molecules in the EU it is becoming increasingly important to hatch healthy chicks without altered function in their immune system and functions.

Another serious threat that might impact on the health status of chickens but also of consumers is represented by the accidental contaminations or voluntary use of some antibiotics of course in broiler feeding but also in breeder hen feeding. Indeed, even though nitro-furans have been banned from the EU, a recent work (McCracken et al., 2005) demonstrated as the residues of these molecules can be transferred from the hen diet $(400 \mathrm{mg} / \mathrm{kg})$ to their offspring and that semicarbazide, a nitro-furazone metabolite, can be found in chicken at slaughter.

\begin{tabular}{|c|c|c|c|}
\hline Compounds in breeder feed & fffects on progeny & Parameter: & Authors \\
\hline $0,5,10 \mu \mathrm{g} / \mathrm{g}$ aflatoxin & No & $\begin{array}{l}\text { Chick weight from hens fed treatment } \\
\text { diets for } 1,2 \text { or } 4 \text { wks }\end{array}$ & Howarth \& Wyatt, (1974) \\
\hline $0,5,10 \mu \mathrm{g} / \mathrm{g}$ aflatoxin & No & $\begin{array}{l}\text { Mortality, feed efficiency and weight gain } \\
\text { at } 14 \mathrm{~d}\end{array}$ & Howarth \& Wyatt, (1974) \\
\hline $0,0.2,1,5 \mathrm{mg} / \mathrm{kg}$ aflatoxin $\mathrm{B}$ & Yes & Decreases cellular and humoral immunity & Qhreshi et al., (1998) \\
\hline $\begin{array}{l}0,10,25,50,100,200,400,{ }^{1} 800 \mathrm{mg} / \mathrm{kc} \\
\text { zearalenone }\end{array}$ & $1 \mathrm{~kg}$ & Body weight at 0 and 21 days & Allen et al., (1981) \\
\hline $\begin{array}{l}0,30,300,3000 \mathrm{mg} / \mathrm{kg} \text { insect regulato } \\
\text { CGA-72662 (Larvadex®) }\end{array}$ & tor & $\begin{array}{l}\text { Depressed body weight at } 14 \text { dwith high } \\
\text { levels in progeny from young dam }\end{array}$ & Brake et al., (1984) \\
\hline $\begin{array}{l}0,30,300,3000 \mathrm{mg} / \mathrm{kg} \text { insect regulator } \\
\text { CGA-72662 (Larvadex®) }\end{array}$ & tor & Feed efficiency and mortality at 14 days & Brake et al., (1984) \\
\hline $\begin{array}{l}400 \mathrm{mg} / \mathrm{kg} \text { furazolidone, nitrofurazone, } \\
\text { furaltadone, nitrofurantoin }\end{array}$ & Yes & $\begin{array}{l}\text { Residues of nitrofurazone metabolite } \\
\text { (semicarbazide) in liver and muscle of day }\end{array}$ & $\begin{array}{l}\text { McCracken et al. (2005) } \\
\text { chicks. }\end{array}$ \\
\hline $\begin{array}{l}400 \mathrm{mg} / \mathrm{kg} \text { furazolidone, nitrofurazone, } \\
\text { furaltadone, nitrofurantoin }\end{array}$ & e, & Residues in chicken at 40 days & McCracken et al. (2005) \\
\hline
\end{tabular}


Also the effects of synthetic compounds, as those used to control pests in poultry houses, on progeny performance have been investigated (Brake et al., 1984). It was clearly demonstrated that feeding hen with diets containing an insect growth regulator negatively affected broiler chicken performance.

\section{FINAL REMARKS}

This area of research, overall, is quite interesting but it is rapidly being superseded by the fast developing technology of in-ovo injection of drugs and nutrients: this will undoubtedly make the possibility of influencing broiler performance much more easily than it has been in the past, giving a real, practical tool to the large scale poultry producers.

\section{REFERENCES}

Atencio A, Edwards HMJr, Pesti GM. Effects of vitamin D3 dietary supplementation of broiler breeder hens on the performance and bone abnormalities of the progeny. Poultry Science 2005; 84:10581068 (a)

Atencio A, Pesti GM, Edwards HMJr. Twenty-five hydroxycholecalciferol as a cholecalciferol substitute in broiler breeder hen diets and its effect on the performance and general health of the progeny. Poultry Science 2005; 84:1277-1285 (b).

Atencio A, Edwards HMJr, Pesti GM. Effects of the level of cholecalciferol supplementation of broiler breeder hen diets on the performance and bone abnormalities of the progeny fed diets containing various level of calcium or 25-hydroxycholecalciferol. Poultry Science 2005; 84:1593-1603 (c).

Berry WD, Hess JB, Lien RJ, Roland DA. Egg production, fertility, and hatchability of breeder hens receiving dietary phytase. Journal of Applied Poultry Research 2003; 12:264-270.

Brake J, Ort JF, Carter TA, Campbell WR. Effect of the insect growth regulator CGA-72662 (Larvadex ${ }^{\circledR}$ ) on broiler breeder production, hatchability and subsequent chick performance. Poultry Science 1984; 63:910-916.

Decuypere $\mathrm{E}, \mathrm{M}$ ichels $\mathrm{H}$. Incubation temperature as a management tool: a review. World's Poultry Science Journal 1992; 48:28-38.

Kidd MT. A treatise on chicken dam nutrition that impacts on progeny. World's Poultry Science Journal 2003; 59:475-494.
Kidd MT, M cDaniel CD, Peebles ED, Barber SJ, Corzo A, Branton SL, Woodworth JC. Breeder hen dietary L-carnitine affects progeny carcass traits. British Poultry Science 2005; 46:97-103.

Haq A, Bailey CA, Chinnah AD. Effect of beta-carotene, canthaxantin, lutein and vitamin $E$ on neonatal immunity of chicks when supplemented in the broiler breeder diets. Poultry Science 1996; 75:1092-1097.

Hossain SM, Barreto SL, Bertechini A, Rios AM, Silva CG. Influence of dietary vitamin $E$ level on egg production of broiler breeders, and on the grow th and immune response of progeny in comparison with the progeny from eggs injected with vitamin E. Animal Feed Science and Technology 1998; 73:307-317.

Latshaw JD. Nutrition - mechanisms of immuno-suppression. Veterinary Immunology and Immunopathology 1991; 30:111-120.

Management Manual. 2005. Ross Breeders, Ross 308.

McCracken RJ, Van Rhijn JA, Kennedy DG. Transfer of nitrofuran residues from parent broiler breeder chickens to broiler progeny. British Poultry Science 2005; 46:287-292.

National Research Council (NRC). 1994. Nutrient requirements of poultry. Washington, DC: National Academy Press, $9^{\text {th }}$ rev.

Peebles ED, Doyle SM, Pansky T, Gerard PD, Latour MA, Boyle CR, Smith TW. Effects of breeder age and dietary fat on subsequent broiler performance (2. Slaughter yield). Poultry Science 1999; 78: 512-515.

Peebles ED, Zumwalt CD, Gerard P.D, Latour M A, Smith TW. M arket age live weight, carcass yield and liver characteristics of broiler offspring from breeder hens fed diets differing in fat and energy contents. Poultry Science 2002; 81:23-29.

Qureshi MA, Brake J, Hamilton PB, Hagler Jr WM , Neisheim S. Dietary exposure of broiler breeders to aflatoxin results in immune dysfunction in progeny chicks. Poultry Science 1998; 77:812-819.

Rebel JMJ, Van Dam JTP, Zekarias B, Balk FRM, Post J, Flores M, Ter Huurne A. Vitamin and trace mineral content in feed of breeders and their progeny: effects of growth, feed conversion and severity of malabsorption syndrome of broilers. British Poultry Science 2004; 45:201-209.

Spratt RS, Leeson S. Effect of protein and energy intake of broiler breeder hens on performance of broiler chicken offspring. Poultry Science 1987; 66:1489-1494.

Virden WS, Yeatman JB, Barber SJ, Zumwalt CD, Ward TL, Johnson $A B$, Kidd $M T$. Hen mineral nutrition impacts progeny liveability. Journal Applied Poultry Research 2003; 12:411-416. 